Prepared for the U.S. Department of Energy under Contract DE-AC05-76RL01830

\title{
Quarterly Report: Microchannel-Assisted Nanomaterial Deposition Technology for Photovoltaic Material Production
}

DR Palo

S Ramprasad

RS Addleman

DM Schut (Voxtel)
BK Paul (OSU)

$\mathrm{C}-\mathrm{H}$ Chang (OSU)

VT Remcho (OSU)

M O'Halloran (CH2M HILL)

April, 2011

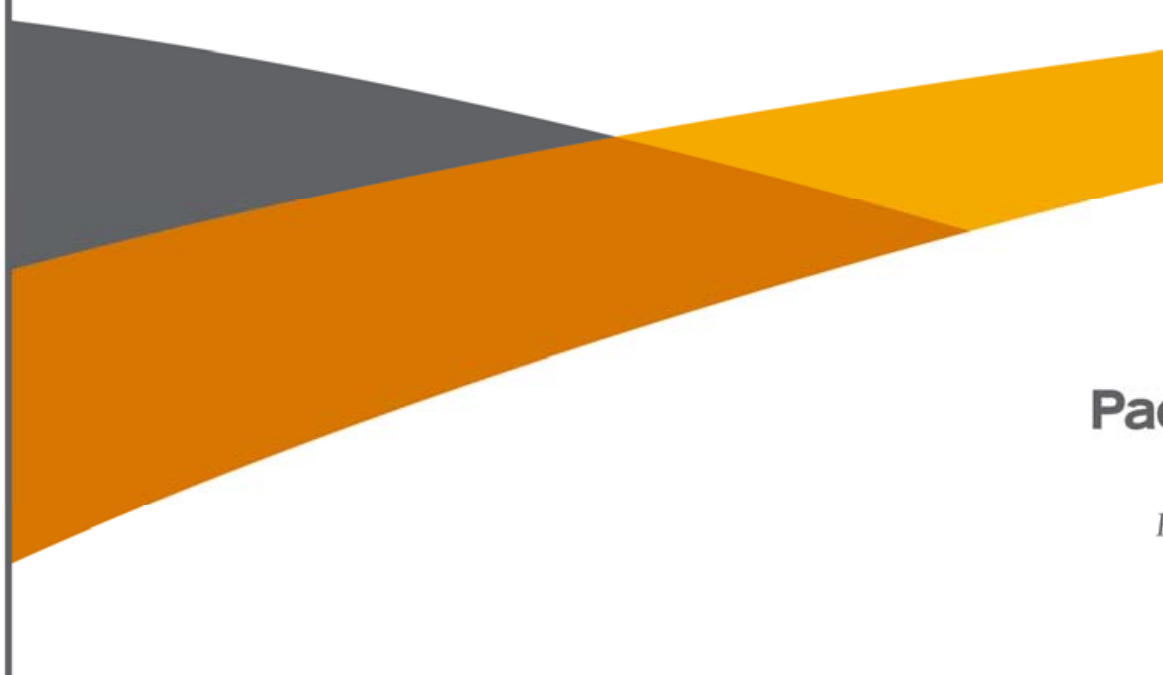




\title{
DISCLAIMER
}

This report was prepared as an account of work sponsored by an agency of the United States Government. Neither the United States Government nor any agency thereof, nor Battelle Memorial Institute, nor any of their employees, makes any warranty, express or implied, or assumes any legal liability or responsibility for the accuracy, completeness, or usefulness of any information, apparatus, product, or process disclosed, or represents that its use would not infringe privately owned rights. Reference herein to any specific commercial product, process, or service by trade name, trademark, manufacturer, or otherwise does not necessarily constitute or imply its endorsement, recommendation, or favoring by the United States Government or any agency thereof, or Battelle Memorial Institute. The views and opinions of authors expressed herein do not necessarily state or reflect those of the United States Government or any agency thereof.

\author{
PACIFIC NORTHWEST NATIONAL LABORATORY \\ operated by \\ BATTELLE \\ for the \\ UNITED STATES DEPARTMENT OF ENERGY \\ under Contract DE-AC05-76RL01830
}

Printed in the United States of America
Available to DOE and DOE contractors from the Office of Scientific and Technical Information,
P.O. Box 62, Oak Ridge, TN 37831-0062;
ph: (865) 576-8401
fax: $(865)$ 576-5728
email: reports@adonis.osti.gov

\begin{abstract}
Available to the public from the National Technical Information Service, U.S. Department of Commerce, 5285 Port Royal Rd., Springfield, VA 22161 ph: (800) 553-6847 fax: $(703) 605-6900$ email: orders@ntis.fedworld.gov online ordering: http://www.ntis.gov/ordering.htm
\end{abstract}

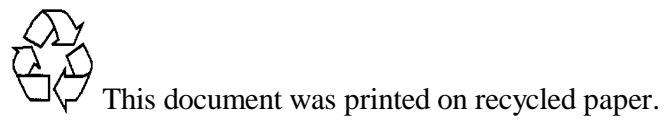




\section{Quarterly Report:}

Microchannel-Assisted

Nanomaterial Deposition

Technology for Photovoltaic Material Production

DR Palo

S Ramprasad

RS Addleman

DM Schut (Voxtel)
BK Paul (OSU)

C-H Chang (OSU)

VT Remcho (OSU)

M O'Halloran (CH2M HILL)

April, 2011

Prepared for the U.S. Department of Energy

under Contract DE-AC05-76RL01830

Pacific Northwest National Laboratory

Richland, Washington 99352 



\section{Quarterly Report}

\section{Microchannel-Assisted Nanomaterial Deposition Technology for Photovoltaic Material Production}

DOE award number:

Recipient:

Project start date:

Project end date:

Principal investigator:

Report date:

Reporting period covered:

PNNL Release Number:
M68008847

Pacific Northwest National Laboratory

17 September, 2008

30 September, 2011

Dr. Daniel R. Palo

30 April, 2011

January 1, 2011 through March 31, 2011

PNNL-20363 


\section{Project Summary}

The primary objective of this project is to develop a nanomanufacturing process which will reduce the manufacturing energy, environmental discharge, and production cost associated with current nano-scale thin-film photovoltaic (PV) manufacturing approaches. The secondary objective is to use a derivative of this nanomanufacturing process to enable greener, more efficient manufacturing of higher efficiency quantum dot-based photovoltaic cells now under development. The work is to develop and demonstrate a scalable (pilot) microreactor-assisted nanomaterial processing platform for the production, purification, functionalization, and solution deposition of nanomaterials for photovoltaic applications.

The high level task duration is shown. Phase I consists of a pilot platform for Gen II PV films along with parallel efforts aimed at Gen III PV quantum dot materials. Status of each task is described below.
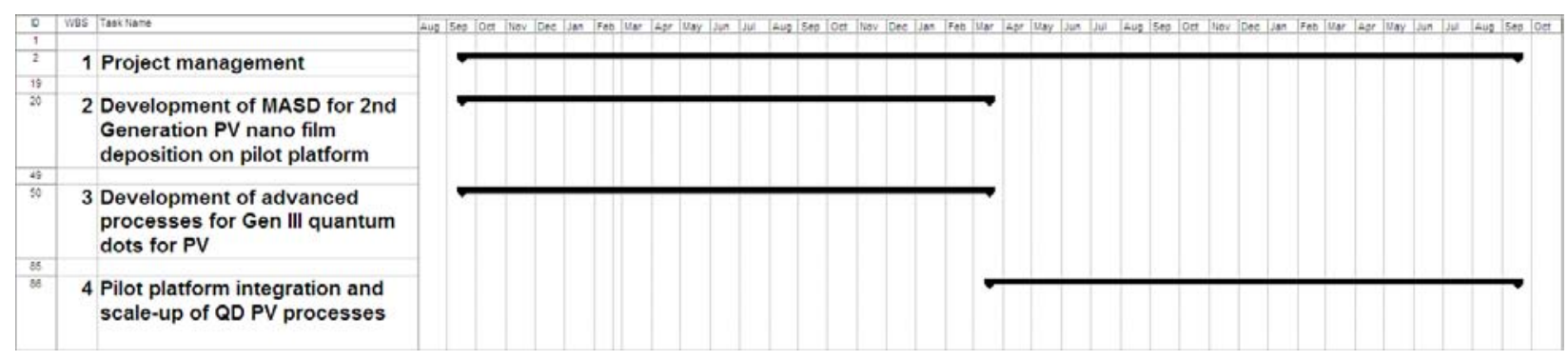

The milestones laid out for this project are shown in Table 1along with indication of their status. Phase I has two major milestones related to Gen II material deposition, and one related to Gen III materials. Phase II is focused mostly on Gen III materials, with a major milestone at the end of the phase.

Table 1. Milestones laid out for the project along with due dates and status.

\begin{tabular}{|l|l|l|l|}
\hline \multicolumn{1}{|c|}{ Milestone } & Due & Status & \multicolumn{1}{c|}{ Comments } \\
\hline $\begin{array}{l}\text { Demonstrate lab-scale deposition of } \\
\text { Gen II films on representative } \\
\text { coupons }\end{array}$ & $\begin{array}{l}6 \\
\text { mos. }\end{array}$ & Complete & \\
\hline $\begin{array}{l}\text { Demonstrate scaled-up deposition of } \\
\text { Gen II films on 6" by 6" substrates }\end{array}$ & $\begin{array}{l}18-22 \\
\text { mos. }\end{array}$ & $\begin{array}{l}\text { Nearly } \\
\text { complete }\end{array}$ & $\begin{array}{l}\text { As focus changes to Task 4 for FY11, this } \\
\text { effort will continue at a lower level. }\end{array}$ \\
\hline $\begin{array}{l}\text { Demonstrate process components for } \\
\text { the production of Gen III PV } \\
\text { materials (synthesis, purification, } \\
\text { deposition) }\end{array}$ & $\begin{array}{l}18-22 \\
\text { mos. }\end{array}$ & Complete & $\begin{array}{l}\text { Transitioned to Task 4 as of October, } \\
\text { 2010 }\end{array}$ \\
\hline $\begin{array}{l}\text { Scale up and integrate the Gen III } \\
\text { PV materials production process }\end{array}$ & $\begin{array}{l}36 \\
\text { mos. }\end{array}$ & Ongoing & $\begin{array}{l}\text { Task was delayed starting due to delays in } \\
\text { achieving Task 2 and Task 3 objectives. } \\
\text { This task still due at 36-month mark } \\
\text { (September, 2011). }\end{array}$ \\
\hline
\end{tabular}




\section{Task 1. Project Management}

\section{Current Status:}

Task 2 is virtually complete, having produced consistent 6-inch CdS films via two different methods. Remaining work on this task includes full documentation of film thickness and characterization (uniformity, composition, crystal structure, topology, etc.), the issuing of several journal manuscripts describing the two methods of producing CdS films on 6-inch platform, and the processing of at least two invention reports submitted within PNNL and OSU.

Task 2 publications and patents/inventions submitted, in preparation, or published are listed below.

- Cadmium Sulfide Thin Film Deposition: A Parametric Study using Microreactor-Assisted Chemical Solution Deposition, Sudhir Ramprasad, Yu-Wei Su, Chih-hung Chang, Brian K. Paul, Daniel R. Palo, submitted to Solar Energy Materials and Solar Cells on January 3, 2011. Manuscript still under review.

- $\quad$ Flow Cell for the Microreactor-Assisted Solution Deposition of CdS Buffer Layers, B. K. Paul, C. L. Hires, Y.-W. Su, C. Chang, S. Ramprasad, D. Palo, manuscript in preparation, 2011.

- Uniform Residence Time in Microreactor-Assisted Solution Deposition of CdS Thin-Films for CIGS Photovoltaic Cells, Clayton Hires, MS Thesis (published), Oregon State University, 2010.

- Characterizations of CdS thin films on FTO substrates fabricated by Microreactor-Assisted Solution Deposition, Yu-Wei Su, Seung-Yeol Han, Wei Wang, S. O. Ryu, S. Ramprasad, D. Palo, and Chih-hung Chang, manuscript in preparation, 2011.

- Production of 150-mm format CdS thin films by continuous solution deposition process, Sudhir Ramprasad, Yu-Wei Su, Chih-hung Chang, Brian K. Paul, Daniel R. Palo, manuscript in preparation, 2011.

- A Device for Making Thin Films, PNNL invention report, January, 2010.

- Techniques to Improve Flow Cell Performance, OSU/PNNL joint invention report, January, 2011.

Task 3 is complete, and there are several journal manuscripts either submitted or in preparation describing our efforts in production, purification, and manipulation of PV-relevant QD materials, including the following.

- Multiple Exciton Collection in a Sensitized Photovoltaic System, Justin B. Sambur, Thomas Novet, B. A. Parkinson, Science, Vol. 330, October 1, 2010, pp 63-66. (Voxtel)

- Inkjet Printed Chalcopyrite CuInxGa1-xSe2 Thin Film Solar Cells, Wei Wang, Yu-Wei Su, Chihhung Chang, Solar Energy Materials and Solar Cells, submitted 2010, under review.

- Continuous Synthesis of SnTe Nanorods, Hyung Dae Jin, and Chih-Hung Chang, manuscript in preparation, 2011

- Continuous Synthesis of CuInSe2 Nanocrystals, Hyung Dae Jin, and Chih-Hung Chang, manuscript in preparation, 2011.

- Nanoparticle purification and separation via membrane filtration, Taehyeong Kim, PhD Dissertation, in preparation, 2011.

- Environmentally Benign Processing of PbS Quantum Dots with Near Critical and Supercritical Ethane, Brad J. Busche, Donnie C. Clubb, Jacky Roberts, Marvin G. Warner, R. Shane Addleman, manuscript in preparation for submission to Green Chemistry, 2011.

- Quantum Dot Solubility and Dispersibility in Near Critical and Supercritical Fluids, Brad J. Busche, Donnie C. Clubb, Jacky Roberts, Marvin G. Warner, R. Shane Addleman, manuscript in preparation for submission to Journal of Physical Chemistry C, 2011.

- Titania Thin Films Designed for Quantum Dot Sensitized Solar Cells, James S. Swensen, Xiaohong S. Li, Cynthia L. Warner, R. Shane Addleman, manuscript in preparation for 
submission to Applied Materials and Interfaces, 2011.

- Green Chemical Production of Low Toxicity Quantum Dots, Cynthia L. Warner, Donnie C. Clubb, R. Shane Addleman, manuscript in preparation for submission to ACS Nano, 2011.

Task 4 is our main focus for the remainder of the project (currently scheduled through September 30, 2011). The work in Task 4 will focus on scale-up of PbS QDs in terms of synthesis, purification, functionalization, and deposition, along with $\mathrm{TiO}_{2}$ substrate production. The $\mathrm{PbS}$ system was chosen for a number of reasons:

- Previous experience of the group with manipulating $\mathrm{PbS}$ materials

- Interest of our partner, Voxtel, in the use of PbS QD-based PV

- Abundant literature information on the batch synthesis and characterization of $\mathrm{PbS}$

- A recent Science publication by Voxtel and partners demonstrating the multi-exciton generation capacity of PbS QDs [Sambur, Novet, and Parkinson Science 330, 63 (2010)] 


\section{Task 2. Development of MASD for 2nd Generation PV nano film deposition on pilot platform}

\section{Task 2 Summary}

Milestones for Task 2 include:

- Demonstrate lab-scale deposition of Gen II films on representative coupons ( 6 months)

- This milestone was met during our initial reporting period.

- Demonstrate scaled-up deposition of Gen II films on 6" by 6" substrates (18-22 months)

- This milestone was essentially met during the previous reporting period, but the work is being repeated and confirmed.

\section{Task 2 Results}

The team has been working in two parallel paths regarding the 6" deposition effort. The original path (version 1), used for initial demonstrations of CdS films on this project, has consisted of a closed-channel flow cell apparatus. In this embodiment, described below, the reactants are mixed and heated before flowing through the flow cell. The flow cell holds the 6" glass substrate in place and constrains a thin flow channel of reactant fluid over the glass. This prevents the substrate from seeing stagnant reactant solution, but provides challenges in terms of flow distribution over the glass and material utilization. This past quarter, we have demonstrated a drastically improved flow distribution achieved through a deflected channel wall approach.

The second embodiment, which is more representative of the potential industrial form of the deposition, consists of a linear stage with several process steps - referred to below as the pilot demonstration. This approach uses a standing liquid film on top of the glass substrate to provide reactants for the film growth. The idea is that several iterations of the liquid application/growth/rinse cycle may be necessary to grow the desired thickness of CdS film. In an automated final embodiment, such iteration is quite feasible and would help reduce material waste, which is a key to the effort described here. The pilot demonstration during this reporting period has focused on film growth and characterization.

Current status for both approaches is described below.

\section{Flow Cell (version 1) Results}

In the previous reporting periods, efforts to address the bubble-induced pin-holes in the CdS film have involved applying a surfactant (Triton 100X) in a pre-flush rinse. While the uniformity of these films were excellent, additional experiments are needed to determine why the mean film thickness varied. Figure 1 and Figure 2 show the temperature profiles of the two substrates during deposition suggesting that a significantly lower deposition temperature could be the cause of these variations. 


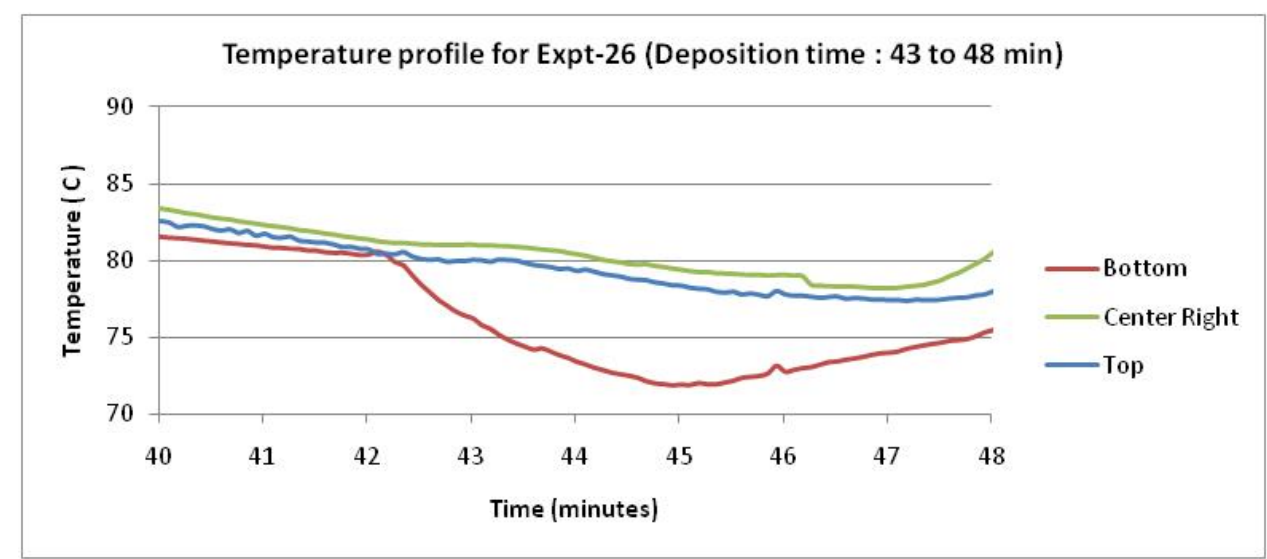

Figure 1. Temperature profile of Expt-26

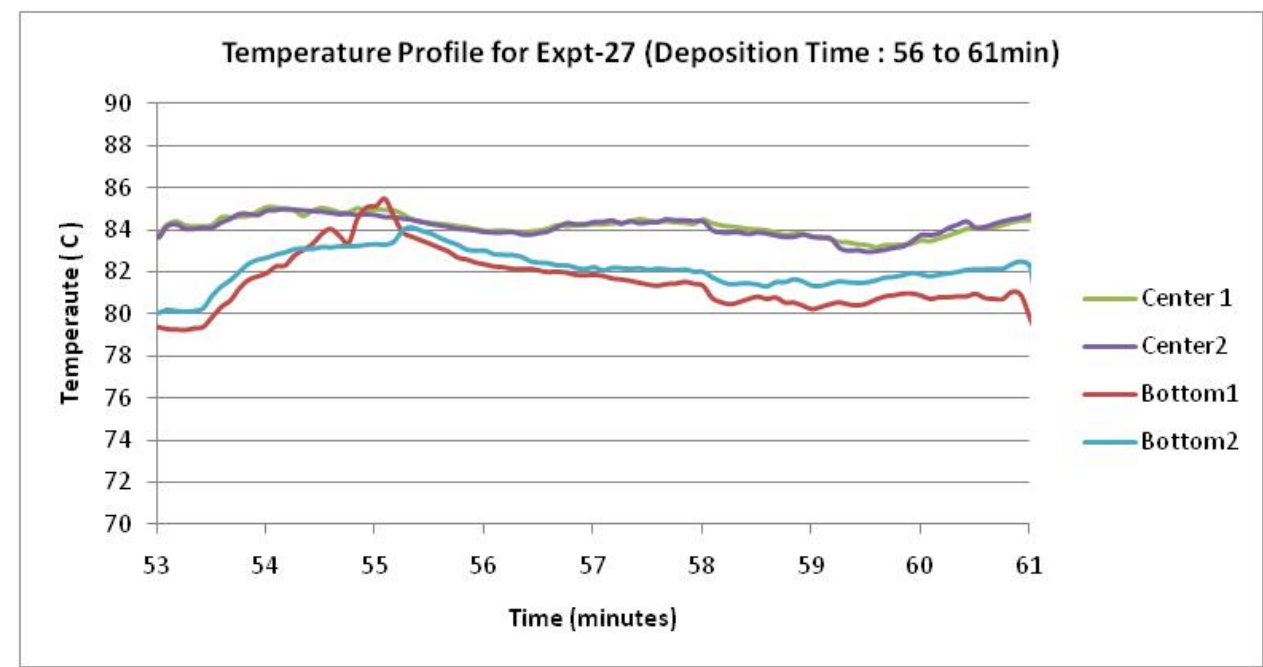

Figure 2. Temperature profile of Expt-27

In the current reporting period, the new V1 setup was installed in the Oregon Process Innovation Center (OPIC) at the Microproducts Breakthrough Institute (MBI) for pursuing additional testing. Figure 9 and 10 shows the block diagram and a picture of the set-up. Based on learnings to date, water and surfactants are used to prime the system via a peristaltic pump. When the system reaches a preset temperature, pinch valves are used to switch from DI water and surfactant to reagents. Reagents A and B are then pumped by a peristaltic pump, mixed together via a microchannel T-mixer and preheated to the proper deposition temperature $\left(\sim 80^{\circ} \mathrm{C}\right)$ within the heat exchanger. The temperature of the substrate $\left(\sim 80^{\circ} \mathrm{C}\right)$ in the flow cell is controlled by a 9x9 inch hot plate. The waste is collected at the outlet for proper disposal.

A test experiment was run successfully using the new set-up on a $6 \times 6$ inch FTO glass using a flow rate of $24 \mathrm{ml} / \mathrm{min}$ and using $0.3 \%$ solution of surfactant in DI water. Characterization of the film is currently underway. 


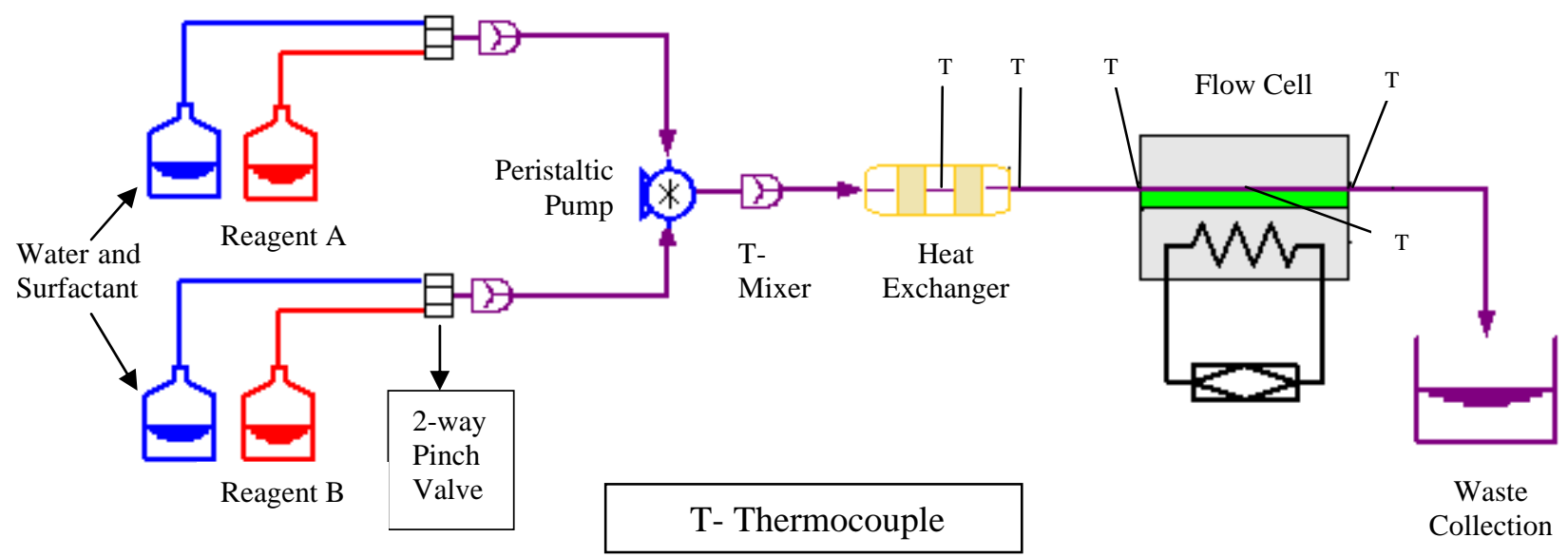

Figure 3. Block diagram of the V1 set-up.

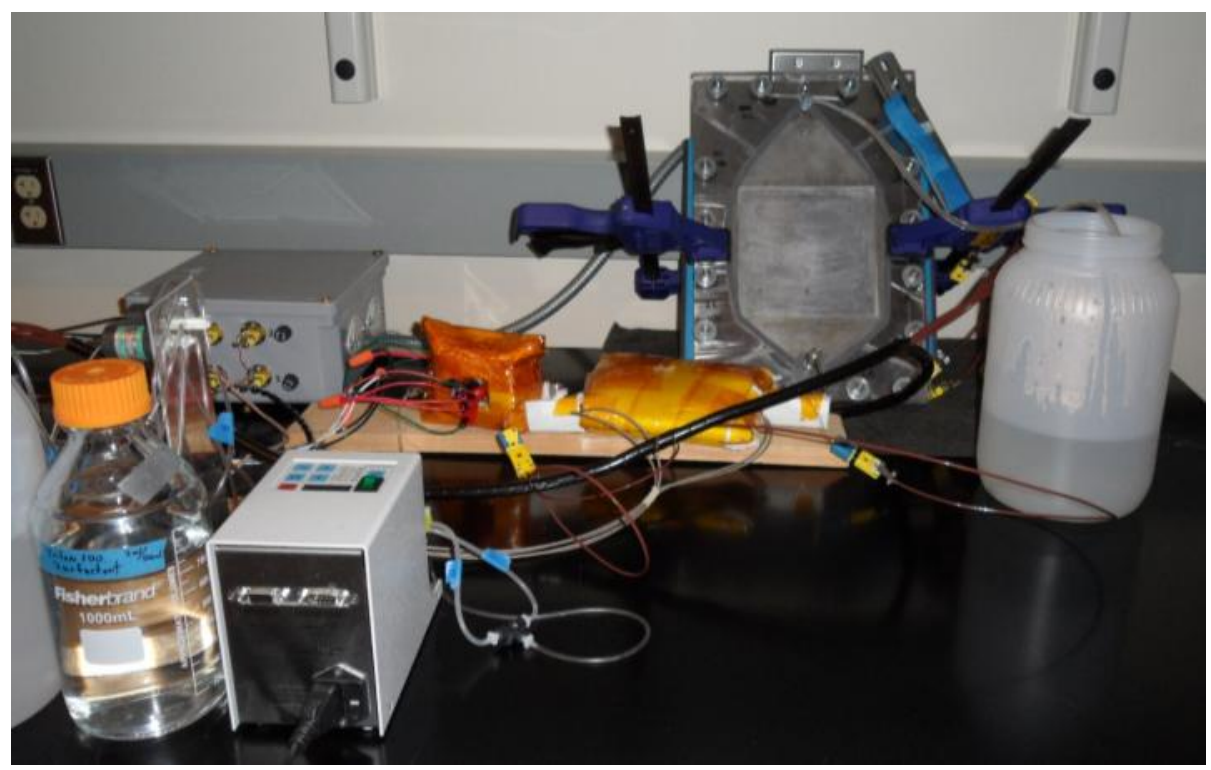

Figure 4. Picture of V1 set-up in the OPIC lab. 


\section{Pilot Deposition}

The current focus on the V2 Pilot deposition unit is to develop reproducible, uniformly coated CdS films on $150 \times 150 \mathrm{~mm}$ glass substrate at the following test conditions. This $2 \times 2$ matrix is meant to explore the effects of process flow rate and deposition time on film uniformity and ultimate Cd yield.

\begin{tabular}{|c|c|c|}
\hline Flow Rate $(\mathrm{ml} / \mathrm{min})$ & 31 & 45 \\
\hline Deposition Time (min) & $\sim 3$ and 6 & 3 and 6 \\
\hline
\end{tabular}

The results reported below are from the low flow rate, $31 \mathrm{ml} / \mathrm{min}$. The deposition time (DT) is the total time the glass substrate is in contact with the CdS reagents and two different DT tested are $\sim 3.4$ and 6.4 minutes. The key to reading the plots is provided in Figure 5, where the numbers 1-6 are locations along the travel direction of the glass, and the letters A-F are locations perpendicular to the travel direction. The results shown in Figure 6 (3-minute deposition) and Figure 7 (6-minute deposition) are the lateral and axial views of the CdS film thickness coated on the substrate. It can be observed from the plot of the axial view for both the 3 and 6 min deposition time, the edges are very thin; while the center of the film is consistently uniform.

Even with the edge thickness issues, the average thickness from the short deposition time samples is $37.3 \mathrm{~nm}+/-4.6 \mathrm{~nm}$ (12\% overall variation), and for the longer deposition time samples the thickness is $90.0 \mathrm{~nm}+/-13.4 \mathrm{~nm}(15 \%$ overall variation). If the few data points of thin film along certain edges were to be corrected through improved processing, the results would be $38.8 \mathrm{~nm}+/-3.2 \mathrm{~nm}$ ( $8 \%$ overall variation) and $93.5 \mathrm{~nm}+/-6.1 \mathrm{~nm}(7 \%$ overall variation), respectively. We are currently working on correcting the edge effect, including looking into larger substrates.

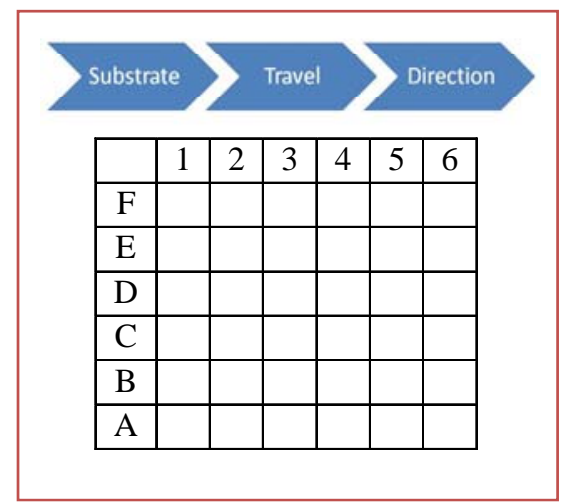

Figure 5. Key to location markers on the glass substrate. Travel direction of the substrate is shown above the matrix. 

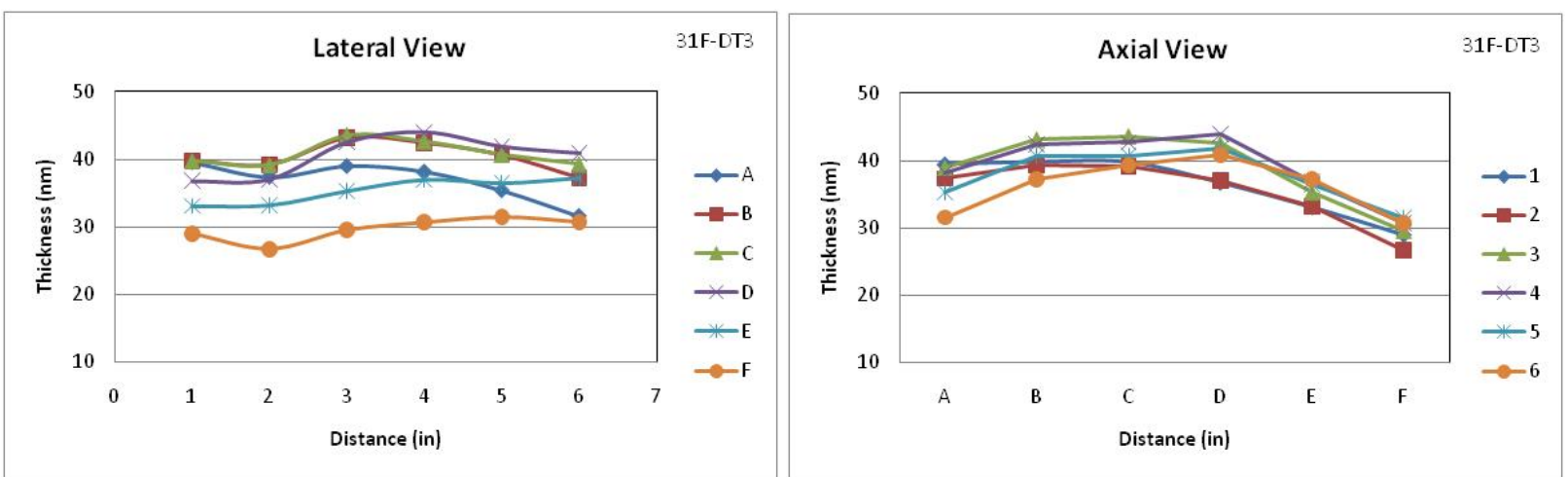

Figure 6. Thickness profile (nm) of CdS films deposited at the lower flow rate and at 3-minute deposition time on 150-mm substrate. In the left plot (lateral view), the substrate travel is from left to right. In the right plot (axial view), substrate travel is out of the page toward the reader. Issues with film uniformity have largely been in the non-travel direction, as can be seen from these plots. Edge effects are the largest apparent issue at this time, as seen in the values for axis $F$.
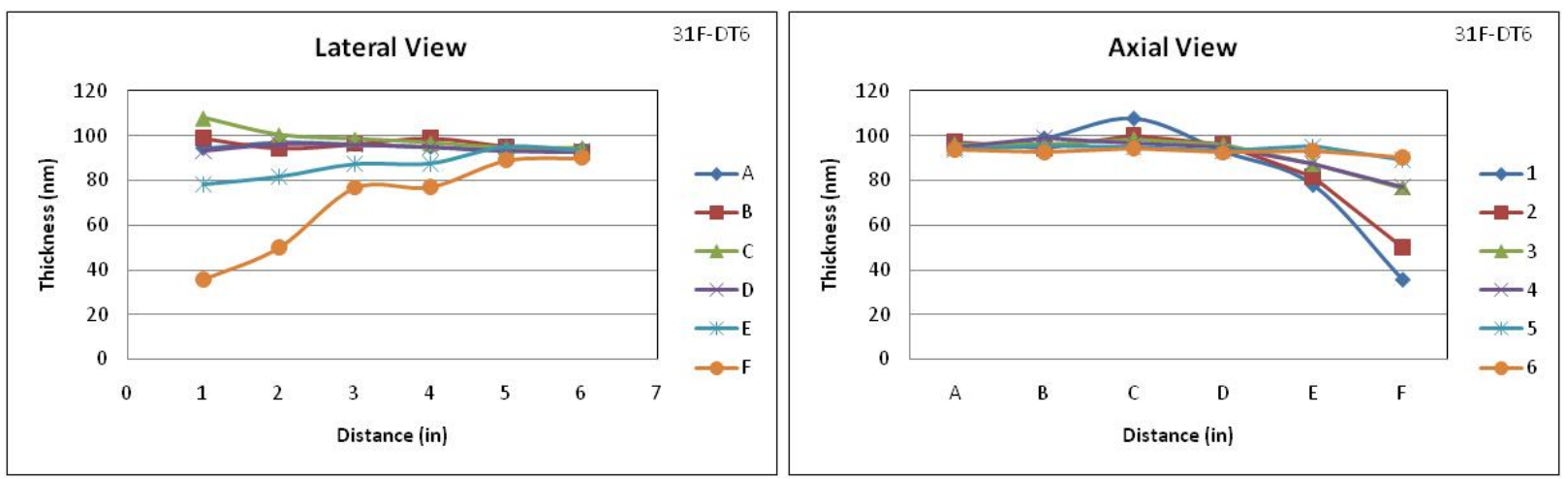

Figure 7. Thickness profile $(\mathrm{nm})$ of CdS films deposited at the lower flow rate and at 6-minute deposition time on 150-mm substrate. In the left plot (lateral view), the substrate travel is from left to right. In the right plot (axial view), substrate travel is out of the page toward the reader. Issues with film uniformity have largely been in the non-travel direction, as can be seen from these plots. Edge effects are the largest apparent issue at this time, as seen in the values for axis $F$. 


\section{Task 4. Pilot platform integration and scale-up of QD PV processes}

\section{QD Production}

\section{Standard Flow Synthesis}

Synthesis of $\mathrm{PbS}$ material was successfully completed with a continuous flow process. Recipe for a 2:1 lead $(\mathrm{Pb})$ precursor to sulfur $(\mathrm{S})$ precursor was replicated from the article "Colloidal PbS Nanocrystals with Size-Tunable-Near-Infrared-Emission: Observation of Post Synthesis Self-Narrowing of the Particle-Size Distribution” by Margaret A. Hines and Gregory D. Scholes. The recipe was scaled up by 5 times for purposes of using the continuous flow process. Experimental equipment consisted of two stainless steel pumps that delivered $\mathrm{Pb}$ and $\mathrm{S}$ precursors. A micromixer with rapid injection provided the means for mixing the precursors before the reactants flowed into Viton tubing. The reaction was carried out in the Viton tubing that was submerged in Silicone Oil at temperatures between $100^{\circ} \mathrm{C}$ and $160^{\circ} \mathrm{C}$. The Viton tubing had a length to give a residence time of 10 minutes, which was chosen arbitrarily for this initial experiment. Flowrates for the $\mathrm{Pb}$ and $\mathrm{S}$ precursors were set at $0.4 \mathrm{~mL} / \mathrm{min}$ and $0.2 \mathrm{~mL} / \mathrm{min}$ respectively. Collection time for products was 8 minutes.

Product appearance was a black to dark-grey color and was continuously flowing without large particles being present. After collection was finalized for each vial, methanol was added to the products followed by centrifuging. Amount of product produced was approximately $0.3 \mathrm{~g}$ for the experiments conducted after decanting and drying of material with nitrogen gas. Toluene was used to re-suspend material for XRD characterization. Figure 8 has the characterization from the first two runs and vials for each run. According to most references, the peaks from the experiment fit closely. (Large peak for Run2Vial2 $\left(\sim 65^{\circ}\right)$ comes from the aluminum holder for the XRD.)

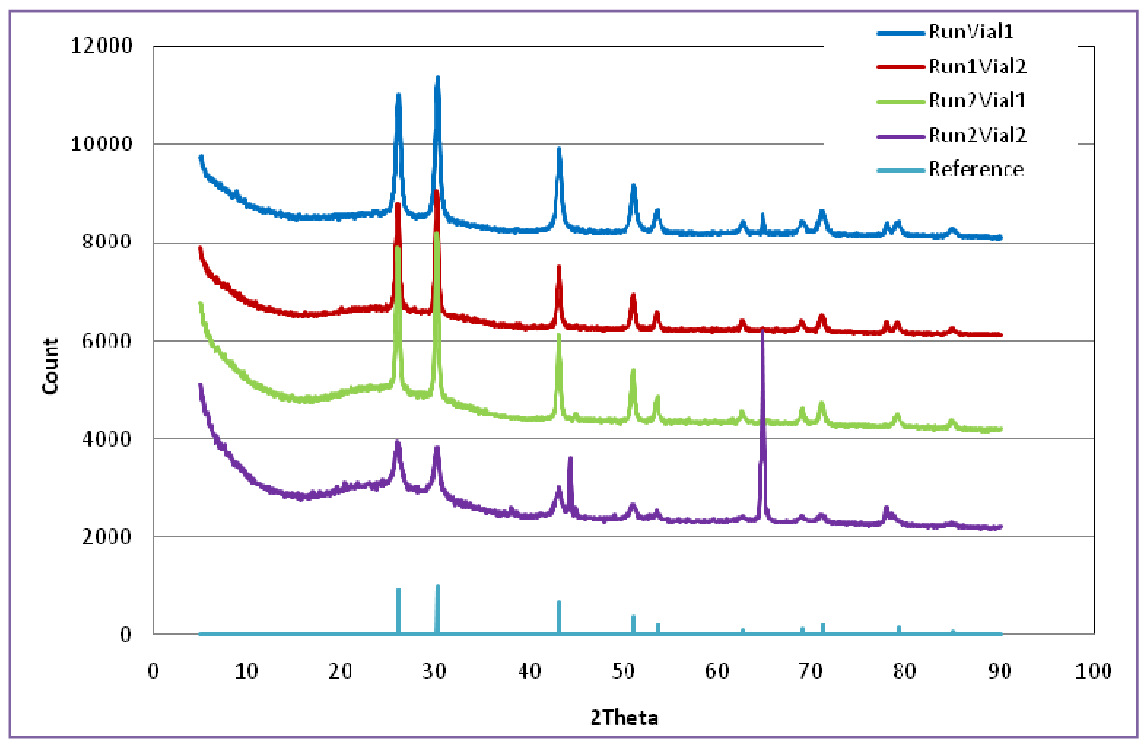

Figure 8. XRD Characterization. Reference taken from Noda, Y et. al, Acta Crystallogr., Sec. C, 43, 1443 (1987). Experimental results fit that of the reference. Large peak at about $65^{\circ}$ is from the aluminum holder for the XRD. (Large peak for Run2Vial2 ( $65 \mathrm{C}$ ) comes from the aluminum holder for the XRD.)

Subsequent experimental results were completed but due to using a hotplate and thermometer to control the temperature of the silicone oil bath, the results could not be reported with confidence. This is due to large fluctuations in temperature between and during runs, when changing the temperature setting. 
An Omega temperature controller has been secured and will be used for future experiments. Future experiments will look at changing residence times for a reaction temperature of $125^{\circ} \mathrm{C}$ and $2: 1 \mathrm{~Pb} / \mathrm{S}$ molar ratio, and changing reaction temperatures at a set residence time and $2: 1 \mathrm{~Pb} / \mathrm{S}$ molar ratio. Also, using trioctylphosphine (TOP) in place of octadecene (ODE) will be looked at for the dilution solvent for bis(trimethylsilyl)sulfide (TMS).

\section{Ultrasonic Flow Synthesis}

An ultrasonic setup capable of delivering $750 \mathrm{~W}(\max )$ from a $13 \mathrm{~mm}$ diameter probe tip has been purchased from Sonics and Materials, Inc. A stainless steel continuous flow cell has also been purchased and has three ports for fluid cycling. Figure 9 shows the ultrasound setup (i) and the continuous flow cell (ii).

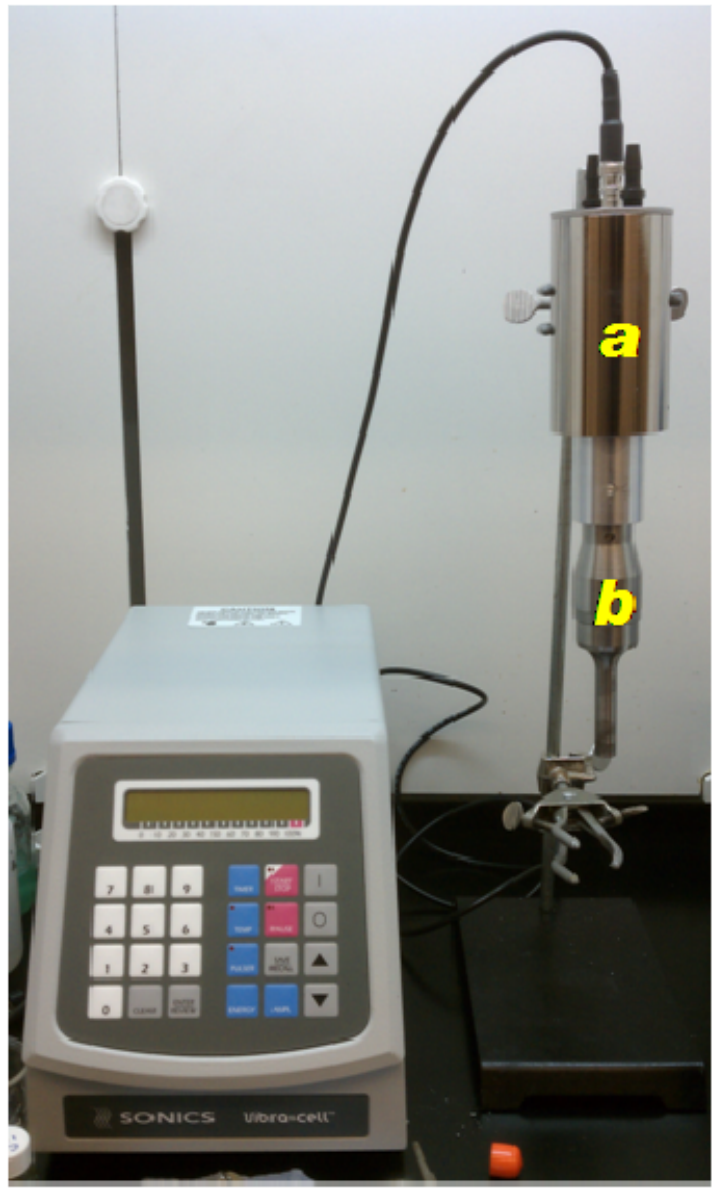

(i)

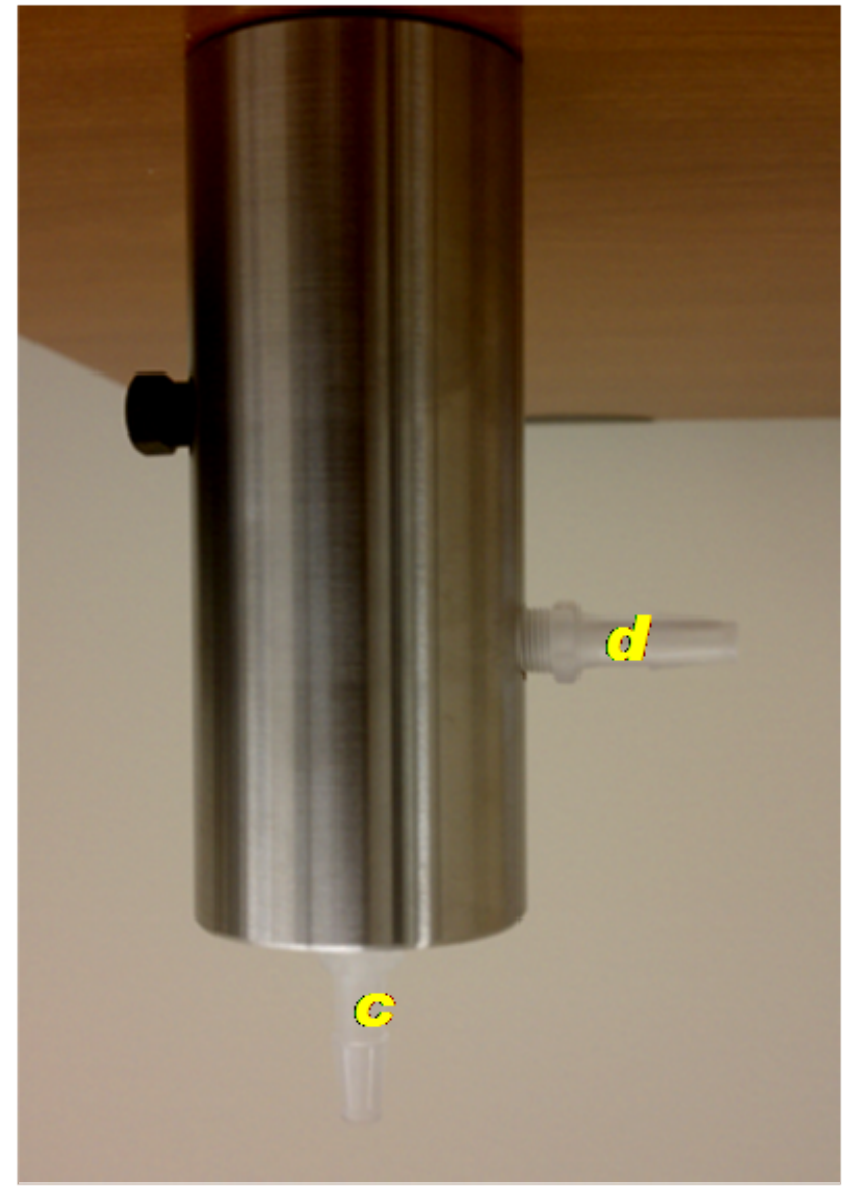

(ii)

Figure 9. Picture of ultrasonic flow synthesis set-up in the OPIC lab showing (a) the ultrasonic converter; (b) ultrasonic horn; (c) the flow cell inlet; and (d) the flow cell outlet

This setup will be used to explore the sonochemical synthesis route for cadmium sulfide (CdS) nanoparticles. The objective of the experiment is to study the effect of US energy on CdS particle size distribution, QD dispersion, and sphericity of particles. A chemical route already identified by Ghows et al [1] consisting of Ethylenediamine, $\mathrm{CS}_{2}, \mathrm{CdCl}_{2} \cdot 2 \mathrm{H}_{2} \mathrm{O}$ will be used. Efforts to adapt a higher temperature route followed by Wan et al [2] for a sonochemical approach will also be pursued. Preliminary trials will consist of running batch synthesis routes for identifying important parameters like reactant concentration, 
ultrasound intensity and exposure time. Based on batch results, a continuous synthesis route will be performed using the flow cell. A suggested modification in the flow cell is to cap the volume around the horn with cork or rubber in order to reduce the residence time of the fluid inside the flow cell. The assynthesized particles coming out of the outlet will be characterized by TEM examination.

\section{References}

[1] Ghows, N., and Entezari, M. H., 2011, "A novel method for the synthesis of CdS nanoparticles without surfactant," Ultrasonics Sonochemistry, 18(1), pp. 269-275.

[2] Wan, Z., Yang, H. W., Luan, W. L., Tu, S. T., and Zhou, X. G., 2010, "Facile Synthesis of Monodisperse CdS Nanocrystals via Microreaction," Nanoscale Research Letters, 5(1), pp. 130-137.

\section{QD Purification}

In normal production, the QD product is suspended in typical liquid solvents (often with unreacted precursors, excess ligands, and other impurities). The QDs must be recovered from this solution (or a similar one based on supercritical fluids) We continue to approach the QD purification effort from two angles. The first is a nanofiltration approach, where the QD solution in standard liquid solvents is processed using various membranes. The second is a degree-of-solubility approach using supercritical and near-critical fluids. Both approaches are described below.

\section{Nanofiltration}

A cross flow filtration system was applied to the purification of $\mathrm{PbS}$ nanoparticle mixtures $\mathrm{PbS} 880$ $(\sim 2.1 \mathrm{~nm})$ and PbS1400 ( 4.9nm) using an HFM-100 ultrafiltration membrane (Koch Co., MWCO=50k, PVDF). UV-Vis-NIR and TEM analyses of feed, retentate, and permeate solutions were utilized to examine membrane performance.

We reported previously that the dead-end flow filtration method successfully removed small particles $(\sim 2.8 \mathrm{~nm})$ from $\mathrm{PbS}$ nanoparticle mixtures by passing the dispersion through HFM-100 membrane. However, reductions in flow rate and retention of particles attributed to filter "caking" are endemic to the dead-end flow filtration method. In this quarter, a cross flow (diafiltration) method was applied for the various $\mathrm{PbS}$ nanoparticle mixtures (Figure 10). A cross-flow, perpendicular to the filtration direction, proved effective in reducing clogging of membrane pores, and is a scalable method that allows continuous-flow operation.

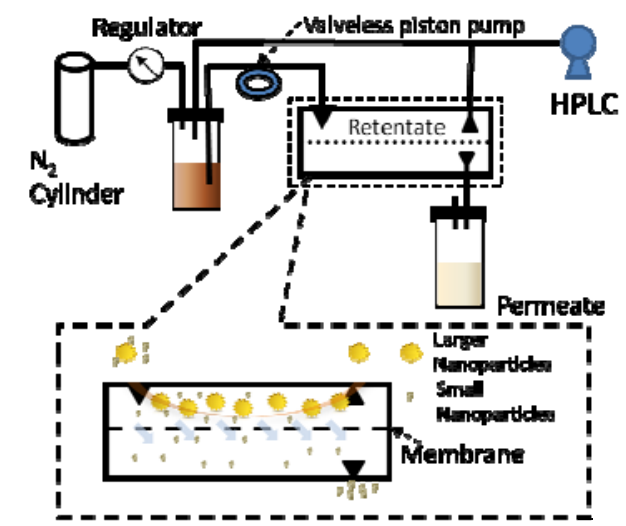

Figure 10. Apparatus assembled to enable cross-flow filtration of nanoparticles. When the mixture is passed through the retentate channel, smaller nanoparticles, residual reactants and impurities pass through the pores of the membrane, resulting in a highly purified nanoparticle stream in the retentate. The feed is drawn from the reservoir and into the membrane through a valveless piston pump. $\mathbf{N}_{2}$ gas is used to maintain a 5psi pressure drop across the membrane. An external HPLC pump provides the fresh solvent to maintain the feed solution volume for diafiltration.

A mixture of $0.5 \mathrm{~g} / \mathrm{mL} \mathrm{PbS} 880$ and $0.5 \mathrm{~g} / \mathrm{mL} \mathrm{PbS} 1400$ was filtered using HFM-100 ultrafiltration. Feed, Retentate, and Permeate solution were collected and analyzed by UV/Vis/NIR and TEM. The removal of PbS880 and retention of the PbS1400 are confirmed by the UV-Vis-NIR spectra of the retentate solution (R). The spectrum of each permeate solution (P1-P5) shows the sequential decrease of PbS880, but the presence of PbS1400. (Figure 11-A) The histogram of feed (Figure 11-B) has the expected bimodal distribution and suggests a mean particle size of $3.7 \pm 1.6 \mathrm{~nm}$. The particle size distribution of the retentate solution (Figure 11-C) exhibits that the PbS1400 nanoparticles have a mean particle size of $4.7 \pm 0.9 \mathrm{~nm}$ after 
filtration (and, more importantly, are highly enriched). These results indicate that the cross-flow filtration method using HFM-100 membrane is capable of effectively purifying and concentrating $\mathrm{PbS}$ nanoparticles in the desired size range.

In the next project quarter, we will work to enhance the cross-flow filtration method for continuous mode of operation and will continue to explore our own silsesquioxane nanofiltration media.

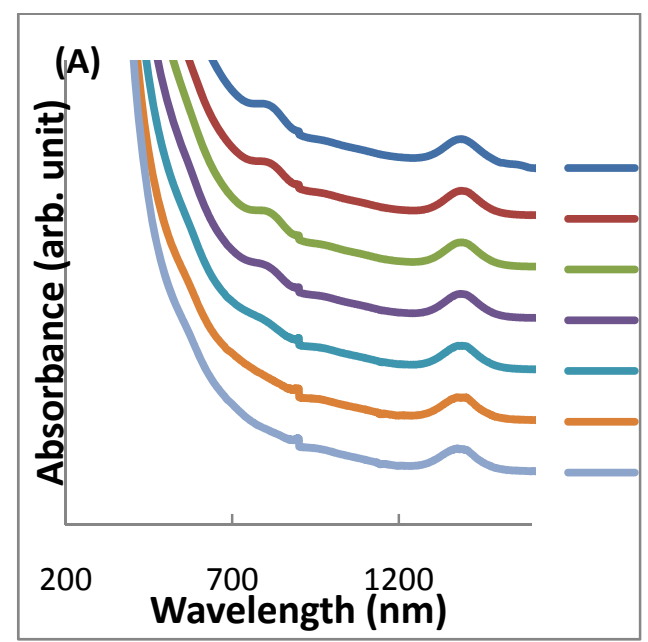

\section{(B) Feed (F)}

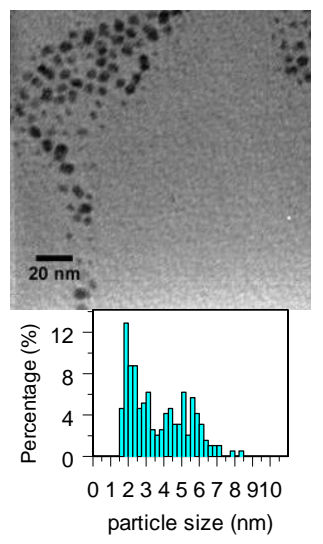

(C) Retentate (R)

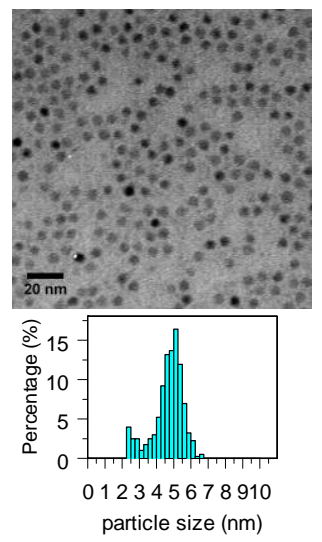

$3.7 \pm 1.6 \mathrm{~nm}$

$4.7 \pm 0.9 \mathrm{~nm}$

Figure 11. (A) UV-Vis-NIR absorbance spectra of Feed (F), Permeate (P), and Retentate (R) of PbS880 and PbS1400 mixtures. Each spectrum is normalized at 1389nm. TEM images and histograms for (B) feed solution of initial mixture of PbS880 and PbS1400 and (C) retentate solution after filtration.

ScF Processing of QD's for Gen III PV

We are exploring greener and more energy efficient methods for the processing of QDs (and other nanoparticles) with supercritical fluids ( $\mathrm{ScFs}$ ) and near critical fluids ( $\mathrm{NcFs}$ ).

\section{Supercritical Processing}

We are exploring greener and more energy efficient methods for the processing of QDs (and other nanoparticles) with supercritical fluids $(\mathrm{ScFs}$ ) and near critical fluids ( $\mathrm{NcFs}$ ). We have mapped the conditions for enabling facile transport of QDs (and other nanoparticles) with ScFs and NcFs. Proof of principle work is complete on a simple method to allow room temperature physical and chemical purification as well as surface functionalization of QDs (and other nanoparticles) with NcFs without significant generation of waste. Manuscripts are being completed for publications, and investigation into IP for this processes are in progress. Experimental work underway is focused on directed deposition and room temperature production of relevant QDs with minimal waste.

\section{Anatase Titania Films for QDs}

Thin composite titania films supporting multiple layers of QDs are needed for complete absorption of the solar spectral energy. The pore sizes available in typical titania films are too small to allow intercalation of the appropriate QDs into the film (i.e., monolayer coverage within pores). PNNL has designed and produced novel titania films with good physical structures for QD intercalation. Physical and electrical properties of the titania films are presently being measured and correlated with structural features and synthetic methodology. Titania films stability, hydrothermal and photonic, are being assessed. Film synthesis methods and materials have been down-selected and final variants are be synthesized for testing. 


\section{Industrial Process Modeling}

A base case manufacturing model for silicon wafer based PV has been developed. The model has not been vetted and does not yet include integration of factory level data which would be used to calculate overall energy, discharges and cost. Vetting and integration at the factory level are anticipated in the next few weeks. The Si-wafer manufacturing model was given a preliminary quick test by inserting a solution deposited Anti-Reflective Coating (ARC) in place of the traditional ARC furnace and moving the process step to the end of the cell line. The test resulted in energy and cost reduction as expected and had an interesting side impact. It seems to show a reduction in the size of a cell line necessary to achieve optimization. If true, this would mean low capital cost cell lines could be integrated with module lines and both could be distributed near solar farm sites. This could have positive implications for job creation in the U.S.

A base case manufacturing model for a thin film CIGS process is partially developed. Development and integration with factory level data will take place next. Coincidently the developer (CH2M HILL) is working on the design of a CIGS factory. They note that the solution deposited CdS buffer layer currently being developed could have an advantage by reducing the quantity of in process material, thus changing the building classification from an "H4" occupancy to a lower cost option. 


\section{Cost Status}

Table 2. PNNL financial report for the reporting period and project-to-date. These numbers apply only to the federally funded portion of the project.

\begin{tabular}{|l|rr|rr|}
\hline Category & $\begin{array}{r}\text { FY11 2nd } \\
\text { Qtr Outlay } \\
\text { (Jan-Feb) }\end{array}$ & $\begin{array}{l}\text { Project to } \\
\text { Date } \\
\text { Outlay }\end{array}$ \\
\hline Labor & $\$$ & 88,728 & $\$$ & 914,018 \\
\hline Travel & $\$$ & 2,420 & $\$$ & 17,105 \\
\hline Service Center & $\$$ & 69 & $\$$ & 8,471 \\
\hline Procurements & $\$$ & 3,823 & $\$$ & 90,913 \\
\hline Subcontract & $\$$ & 84,461 & $\$$ & 478,660 \\
Outlays & $\$$ & 179,501 & $\$ 1,509,167$ \\
\hline Unliquidated Obligations & $\$ 1149,148$ & $\$$ & 149,148 \\
\hline Total Outlays/Obligations & $\$ 328,649$ & $\$ 1,658,315$ \\
\hline Federal Funds Authorized & $\$ 1,821,747$ & $\$ 1,821,747$ \\
\hline Unobligated Balance of Funds & & \multicolumn{2}{|c|}{$\mathbf{1 6 3 , 4 3 2}$} \\
\hline
\end{tabular}

Table 3. Summary of ONAMI-based cost share spent at Oregon State University. Labor, Supplies, Travel, and Capital categories are ONAMI cash expended. Waived Overhead represents OSU overheads that would normally be levied on the Labor and Supplies categories.

\begin{tabular}{|l|rr|rr|}
\hline Category & \multicolumn{2}{|c|}{$\begin{array}{c}\text { FY11 2nd Quarter } \\
\text { Outlay } \\
\text { (Jan-Mar) }\end{array}$} & \multicolumn{1}{c|}{$\begin{array}{c}\text { Total Project } \\
\text { Outlay }\end{array}$} \\
\hline Labor & $\$$ & $(13,801)$ & $\$$ & 100,466 \\
\hline Supplies & $\$$ & 7,506 & $\$$ & 88,451 \\
\hline Travel & $\$$ & 642 & $\$$ & 10,761 \\
\hline Capital Equipment & $\$$ & - & $\$$ & 48,253 \\
\hline Outlays & $\$$ & $(5,653)$ & $\$$ & 247,931 \\
\hline Waived Overhead & $\$$ & $(28)$ & $\$$ & 62,571 \\
\hline Total ONAMI/OSU Cost Share & $\$$ & $(5,681)$ & $\$$ & 310,502 \\
\hline
\end{tabular}

Table 4. Summary of Voxtel in-kind cost share spent on the project this quarter and to date.

\begin{tabular}{|l|cr|rr|}
\hline Category & $\begin{array}{c}\text { FY11 2nd } \\
\text { Quarter Outlay } \\
\text { (Jan-Mar) }\end{array}$ & $\begin{array}{c}\text { Total Project } \\
\text { Outlay }\end{array}$ \\
\hline Labor & $\$$ & - & $\$$ & 41,649 \\
\hline Materials & $\$$ & - & $\$$ & 13,630 \\
\hline Analysis & $\$$ & - & $\$$ & 1,862 \\
\hline Total Voxtel Cost Share & $\$$ & - & $\$$ & 57,141 \\
\hline
\end{tabular}


Table 5. Summary of CH2M HILL in-kind cost share spent on the project this quarter and to date.

\begin{tabular}{|c|c|c|c|}
\hline Category & & $\begin{array}{l}\text { 2nd } \\
\text { irter } \\
\text { lay } \\
\text { Mar) }\end{array}$ & $\begin{array}{c}\text { Total } \\
\text { Project } \\
\text { Outlay }\end{array}$ \\
\hline Labor & $\$$ & 5,856 & $\$ 14,572$ \\
\hline Materials & & & $\$$ \\
\hline Analysis & & & $\$$ \\
\hline Total CH2M HILL Cost Share & $\$$ & 5,856 & $\$ 14,572$ \\
\hline
\end{tabular}

Table 6. Summary of federal funds expended, non-federal cost share, and cost share percentage.

\begin{tabular}{|l|r|}
\hline \multicolumn{1}{|c|}{ Category } & $\begin{array}{c}\text { Project to } \\
\text { Date } \\
\text { Federal Fund Outlays }\end{array}$ \\
\hline Non-Federal Cost Share Outlays & $1,658,315$ \\
\hline Cost Share as Percent of Total Outlays & $\$ \quad 382,215$ \\
\hline
\end{tabular}

